\title{
Pengaruh Return On Asset dan Program Penilaian Peringkat Terhadap Pengungkapan Islamic Social Reporting Dengan Ukuran Perusahaan Sebagai Variabel Intervening
}

(Studi Kasus Pada Perusahaan yang terdaftar di Indeks Saham Syariah Indonesia)

\author{
Lis Djuniar ${ }^{1}$, Ita Ningsih ${ }^{2}$ \\ ${ }^{1}$ Akuntansi, FEBI Universitas Muhammadiyah Palembang, lisdiuniar@gmail.com \\ ${ }^{2}$ Akuntansi, FEBI Universitas Muhammadiyah Palembang, ningsihita126@gmail.com
}

\begin{abstract}
ABSTRAK
Penelitian ini bertujuan untuk mengetahui pengaruh return on asset dan program penilaian peringkat terhadap pengungkapan islamic social reporting dengan ukuran perusahaan sebagai variabel intervening,studi kasus pada perusahaan yang terdaftar di Indeks Saham Syariah Indonesia. Jenis penelitian ini adalah penelitian asosiatif. Penelirian ini dilakukan di Bursa Efek Indonesia. Variabel dalam penelitian ini adalah pengaruh return on asset dan program penilaian peringkat terhadap pengungkapan islamic social reporting dengan ukuran perusahaan sebagai variabel intervening. Data yang digunakan adalah data sekunder. Analisis data yang digunakan kuantitatif dan kualitatif. Hasil penelitian variabel return on asset, program penilaian peringkat berpengaruh secara simultan terhadap islamic social reporting, return on asset tidak berpengaruh terhadap islamic social reporting, ukuran perusahaan berpengaruh tehadap islamic social reporting, dan memiliki pengaruh tidak langsung terhadap islamic social reporting dengan ukuran perusahaan sebagai variabel intervening.
\end{abstract}

Kata Kunci : Return On Asset, PROPER, ISR, Ukuran Perusahaan

\section{A. PENDAHULUAN}

Ekonomi Islam sedang

mengalami perkembangan yang cukup pesat. Semakin banyak perusahaan yang berasaskan syariah bermunculan seiring berjalannya waktu. Tidak terkecuali pada pasar modal syariah. Di Indonesia salah satu instrumen syariah yang terkait dengan pasar modal adalah Indeks Saham Syariah Indonesia (ISSI). Perusahaan yang terdaftar di ISSI diharapkan untuk menyajikan suatu dimensi religi. Termasuk dalam pengungkapan laporan tanggung jawab sosial perusahaan. Hal tersebut bertujuan memberi manfaat bagi investor muslim maupun pihak lain yang terkait.'

Dampak positif dari berkembangnya perusahaan berskala besar dengan bidang usaha yang semakin beragam menciptakan lapangan pekerjaan tersedia cukup luas bagi masyarakat. Perusahaan juga dapat menimbulkan persoalan dan lingkungan. Sebagai contoh, kasus PT Freeport dengan masyarakat suku di Papua, kasus banjir lumpur panas oleh PT Lapindo Brantas di Sidoarjo, kasus Pencemaran Teluk Buyat di Minahasa Selatan oleh PT Newmont Minahasa Raya adalah fakta empiris kerugian sosial dan lingkungan yang harus diderita oleh masyarakat akibat industrialisasi.

Melihat dari sisi negatif dampak yang ditimbulkan oleh perindustrian tersebut, maka suatu entitas bisnis dituntut untuk memelihara lingkungan alam yang ada disekitarnya. Berbagai perusahaan sudah mulai menunjukkan komitmennya untuk menerapkan praktik tanggung jawab sosial perusahaannya. Hal itu mendapat dukungan penuh dari pemerintah sehubungan dengan 
diterbitkannya Undang-undang No.40 Tahun 2007 Pasal 74 tentang Perseroan Terbatas dan Tanggungjawab Sosial dan Lingkungan. Dikemukakan dalam isi pasal tersebut bahwa perseroan yang menjalankan kegiatan usahanya di bidang dan/atau berkaitan dengan sumber daya alam wajib melaksanakan tanggungjawab sosial dan lingkungan.

Tanggung jawab sosial merupakan tanggungjawab yang dilakukan atas kegiatan oleh suatu perusahaan dalam rangka interaksi dengan lingkungan sekitarnya. Kegiatan tanggungjawab sosial tersebut dipublikasikan melalui laporan khusus atau istilahnya laporan berkelanjutan. Tanggung jawab sosial yang ada di perusahaan dan dilakukan umumnya termasuk berakar pada dua teori utama, yaitu teori legitimasi dan teori stakeholders. Kedua teori ini sarat dengan nilai-nilai kapitalis yang mengutamakan kepentingan pemilik dan cenderung mengabaikan hak-hak stakeholders yang lain. Nilai-nilai material menjadi fokus utama sehingga nilai-nilai spiritual menjadi terpinggirkan. Sebagai akibatnya praktek tanggungjawab sosial menjadi suatu strategi untuk melegitimasi kegiatan perusahaan yang lain. Menjadi suatu kamuflase, membangun citra, memberikan informasi yang baik kepada masyarakat demi keuntungan maksimal pemegang saham dan bersifat sukarela (voluntary).

Saat ini belum banyak yang mengetahui bahwa konsep tanggungjawab sosial perusahaan kini tidak hanya berkembang di ekonomi konvensional tetapi juga dalam ekonomi islam. Konsep tanggungjawab sosial perusahaan dalam Islam erat kaitanya dengan perusahaan - perusahaan yang menjalankan kegiatan bisnis yang sesuai dengan konsep syariah. Perusahaan-perusahaan tersebut diharapkan dapat melaksanakan tanggung jawab perusahaannya secara baik dan konsisten terhadap nilai-nilai Islam. Nilai-nilai Islam yang dibawa oleh Rasulullah SAW dapat digunakan sebagai landasan tanggungjawab perusahaan, seperti halnya yang telah dijalankan pada perusahaan konvensional. Konsep ini dalam Islam lebih menekankan pada bentuk ketaqwaan umat manusia kepada Allat SWT dalam dimensi perusahaan. Nilai-nilai Islam sesungguhnya memiliki hubungan yang relevan dan memiliki kontribusi terhadap konsep tanggungjawab sosial perusahaan yang telah berkembang hingga saat ini.

Islamic Social Reporting adalah standar pelaporan kinerja sosial perusahaan-perusahaan yang menjalankan kegiatan bisnis dengan prinsip syariah dan disampaikan perusahaan pada laporan tahunannya. Secara khusus indeks ini adalah peluasan dari standar pelaporan kinerja sosial yang meliputi harapan masyarakat tidak hanya mengenai peran perusahaan dalam perekonomian, tetapi juga peran perusahaan dalam perspektif spiritual.

Kinerja keuangan merupakan indikator dalam menilai kondisi keuangan perusahaan yang diantaranya dapat diukur dengan rasio likuiditas yaitu current ratio. Current Ratio (CR) merupakan rasio yang biasa digunakan untuk mengukur kemampuan perusahaan dalam membayar kewajiban jangka pendek atau utang yang segera jatuh tempo. Rasio ini dapat mengukur seberapa banyak aktiva lancar yang tersedia untuk menutupi kewajiban jangka pendek perusahaan. 
$\begin{array}{rrr}\text { Kinerja } & \text { lingkungan adalah } \\ \text { mekanisme } & \begin{array}{r}\text { perusahaan secara } \\ \text { sukarela }\end{array} & \text { menginterasikan }\end{array}$ perhatiannya terhadap lingkungan ke dalam operasi dan interaksinya dengan stakeholders, yang melebihi tanggung jawab organisasi. Keikutsertaan perusahaan dalam program penilaian peringkat (PROPER) sendiri sudah memberikan positif akan keperdulian lingkungan dan sosial perusahaan. Sistem peringkat kerja PROPER mencakup pemeringkatan perusahaan dalam lima (5) warna dengan tujuh kategori yakni emas, hijau, biru, merah, dan hitam. Warna emas merupakan peringkat tertinggi berurutan dengan warna lain hingga warna hitam sebagai warna terendah.

Hery (2017) mendefinisikan rasio profitabilitas merupakan rasio yang digunakan untuk mengukur kemampuan perusahaan dalam menghasilkan laba dari aktivitas normal bisnisnya. Perusahaan yang memperoleh laba maksimal seperti yang telah ditargetkan dapat berbuat banyak bagi kesejahteraan pemilik, karyawan, serta meningkatkan mutu produk dan melakukan investasi baru.

Tujuan dari penelitian ini adalah untuk mengetahui pengaruh Return On Asset dan Program Penilaian Peringkat terhadap pengungkapan islamic social reporting dengan ukuran perusahaan sebagai variabel intervening pada perusahaan yang terdaftar di Indeks Saham Syariah Indonesia.

\section{B. KAJIAN PUSTAKA}

\section{1) Islamic Social Reporting}

Yasir (2017) pelaksanaan tanggungjawab sosial perusahaan secara syariah didasarkan pada prinsip dan falsafah yang digali dari Al-Qur'an dan as-Sunnah serta menjadi pedoman dalam berbagai aktivitas kehidupan. Islamic Social Reporting (ISR) adalah perpanjangan pelaporan sosial yang meliputi tidak hanya harapan dewan pengurus atas pandangan masyarakat terhadap peran perusahaan dalam ekonomi tetapi juga memenuhi perspektif spiritual untuk pengguna laporan keuangan muslim. ISR bertujuan untuk meningkatkan transparasi dari aktivitas bisnis dengan menyediakan informasi yang relevan dalam memenuhi kebutuhan spiritual dari pengguna laporan perusahaan yang muslim. Selain itu, indeks ISR menekankan pada keadilan sosial terkait pelapor mengenai lingkungan, kepentingan minoritas dan karyawan

\section{2) Return On Asset}

Irham (2015) mendefinisikan return on asset adalah suatu analisis yang dilakukan untuk melihat sejauh mana suatu perusahaan telah melaksanakan dengan menggunakan aturan-aturan pelaksanaan keuangan secara baik dan benar. Kinerja perusahaan secara umum merupakan gambaran prestasi yang dicapai perusahaan operasionalnya. Kinerja perusahaan dapat diukur dengan menganalisa dan mengevaluasi laporan keuangan. Kinerja menunjukan suatu yang berhubungan dengan kekuatan serta kelemahan suatu perusahaan. Terdapat berbagai analisis, termasuk berbagai rasio keuangan, yang dapat digunakan untuk melakukan penilaian sebuah perusahaan.

\section{3) Kinerja Lingkungan}

Irham (2015) mendefinisikan lingkungan adalah segala yang berada di luar organisasi dan selama ini dianggap memberi pengaruh kepada mereka yang dilihat disekitar lingkungan tersebut. Kinerja lingkungan merupakan mekanisme 
perusahaan secara sukarela mengintegrasikan perhatiannya terhadap lingkungan ke dalam operasi dan interaksinya dengan stakeholders, yang melebihi tanggung jawab organisasi. Persoalan kerusakan lingkungan yang dilakukan oleh perusahaan pada era sekarang ini telah dipandang sebagai persoalan serius dan tidak bisa dilihat sebelah mata. Kategori bisnis yang dibangun memiliki pengaruh kecil, sedang dan besar pada dampak perusakan lingkungan, oleh karena itu Kementrian Lingkungan Hidup Republik Indonesia membuat program penilaian mengenai kinerja lingkungan perusahaan.

\section{4) Ukuran Perusahaan}

Hery (2017: 97) mendefinisikan ukuran perusahaan merupakan skala yang menunjukan besar atau kecilnya suatu perusahaan. Undang-undang No.20 Tahun 2008 mengklasifikasi ukuran perusahaan ke dalam 4 kategori yaitu usaha mikro, usaha menengah, dan usaha besar. Pengklasifikasian ukuran perusahaan tersebut didasarkan pada total aset yang dimiliki dan total penjualan tahunan perusahaan tersebut.

\section{5) Hipotesis}

Perumusan hipotesis merupakan langkah ketiga dalam penelitian setelah mengemukakan kerangka berpikir dan landasan teori. Hipotesis merupakan jawaban sementara dari permasalahan yang akan diteliti. Hipotesis disusun dan diuji untuk menunjukkan benar atau salah dengan cara terbebas dari nilai dan pendapat peneliti yang menyusun dan menguji. Berdasarkan hasil dari penelitian-penelitian terdahulu, maka dalam penelitian ini peneliti merumuskan hipotesis sebagai berikut:
1. H1 : Variabel return on asset dan program penilaian peringkat berpengaruh terhadap islamic social reporting.

2. $\mathrm{H} 2 \mathrm{a}$ : Variabel return on asset berpengaruh terhadap islamic social reporting.

$\mathrm{H} 2 \mathrm{~b}$ : Variabel program ppenilaian peringkat berpengaruh terhadap islamic social rreporting. nilai perusahaan.

3. $\mathrm{H} 3 \mathrm{a}$ : Variabel secara return on asset berpengaruh terhadap ukuran perusahaan. modal.

$\mathrm{H} 3 \mathrm{~b}$ : Variabel programpenilaian peringkat berpengaruh terhadap ukuran perusahaan.

4. H4 : Variabel return on asset dan program penilaian peringkat melalui ukuran perusahaan berpengaruh terhadap islamic social reporting.

\section{METODE PENELITIAN}

Desain penelitian yang digunakan adalah asosiatif untuk mengetahui pengaruh return on asset dan program penilaian peringkat terhadap islamic social reporting dengan ukuran perusahaan sebagai variabel intervening. Lokasi penelitian dilakukan pada perusahaan yang terdaftar di Bursa Efek Indonesia (BEI). Lokasi penelitian tersebut dapat diakses melalui situs resmi Bursa Efek Indonesia (BEI), yaitu www.idx.co.id.

Data yang dapat digunakan dalam suatu penelitian dapat dibagi menjadi dua bagian, yaitu data kualitatif dan data kuantitatif. Jenis data yang digunakan dalam penelitian ini adalah data kuantitatif, dimana data kuantitatif merupakan data yang berbentuk angka. Data kuantitatif 
yang dimaksud dalam penelitian ini adalah laporan keuangan pada perusahaan yang terdapat di Bursa Efek Indonesia (BEI). Sumber data itu sendiri dapat dibagi menjadi dua, yaitu sumber data primer dan sumber data sekunder.

Penelitian ini menggunakan sumber data sekunder, dimana data diperoleh melalui pihak mempublikasikan. Data tersebut diperoleh melalui situs resmi Bursa Efek Indonesia (BEI). Populasi yang diteliti adalah perusahaan yang terdaftar Bursa Efek Indonesia (BEl) periode 2015/2017. Sampel yang digunakan dipenelitian ini sejumlah 10 perusahaan. Sampel merupakan bagian dari jumlah dan karakteristik yang dimiliki oleh suatu populasi. Teknik sampling yang digunakan dalam penelitian ini adalah menggunakan purposive sampling.

Metode pengumpulan data yang digunakan dalam penelitian ini adalah metode observasi nonpartisipan, dimana peneliti tidak terlibat secara langsung dan hanya meneliti saja. Metode observasi nonpartisipan ini dilakukan dengan mengamati dan menganalisis laporan keuangan sektor properti dan real estate yang dapat diakses melalui situs resmi Bursa Efek Indonesia (BEI).

\section{HASIL PENELITIAN}

Penelitian ini menggunakan sampel sebanyak 30 perusahaan yang terdaftar di BEI periode 20152017. Setelah dilakukan pertimbangan dan menentukan kriteria-kriteria pada perusahaan, maka sampel yang di uji menjadi 10 perusahaan maka data tersebut lolos uji normalitas.

\section{1) Hasil Analisis Deskriptif}

Analisis ini digunakan untuk mendeskripsikan data pada suatu penelitian, dimana variable-variabel dalam penelitian ini yaitu variabel return on asset, program penilaian peringkat terhadap islamic social reporting dengan ukuran perusahaan sebagai variabel intervening, pada perusahaan yang terdaftar di indek saham syariah indonesia tahun 20152017. Berikut hasil analisis data dengan menggunakan statistik deskriptif dapat dilihat pada tabel sesuai dengan variabel yang diteliti, yaitu sebagai berikut:

\section{Tabel 1}

Descriptive Statistics

Statistik Deskriptif

\begin{tabular}{|l|c|c|c|c|c|}
\hline & $\mathrm{N}$ & Min & Max & Mean & Std. Deviation \\
\hline ROA & 30 & .32 & .52 & .4159 & .05392 \\
PROPER & 30 & 2.40 & 7.49 & 3.0070 & 1.04863 \\
ISR & 30 & 1.10 & 1.61 & 1.3892 & .21513 \\
UP & 30 & 28.71 & 32.16 & 30.4643 & 1.27465 \\
Valid N (listwise) & 30 & & & & \\
\hline
\end{tabular}

Dari tabel diatas dapat diperoleh hasil bahwa dengan analisis statistik deskriptif dapat diketahui jumlah sampel variabel islamic social reporting dengan nilai $\mathrm{n}=30$ memiliki nilai mean sebesar 0,4159 , nilai standart deviation sebesar 0,05392, nilai minimum sebesar 0,32 dan nilai maximum 0,52. Variabel return on asset dengan nilai $\mathrm{n}=30$ nilai mean sebesar 3,0070, nilai standard devisiation sebesar 1,04863, nilai 
minimum sebesar 2,40 dan nilai maximum sebesar 7,49. Variabel Program Penilaian Peringkat dengan nilai $\mathrm{n}=30$ memiliki nilai mean sebesar 1,3892, nilai standard devisiation sebesar 0,21523, nilai minimum sebesar 1,10 dan nilai maximum 1,61. Variabel ukuran Perusahaan dengan nilai $n=30$ memiliki nilai mean sebesar 30,4643 nilai standard devisiation sebesar
1,27465, nilai minimum sebesar 28,71 dan nilai maximum 32,16.

\section{2) Hasil uji determinasi $\left(\mathbf{R}^{2}\right)$ \\ Koefiisen determinasi}

bertujuan untuk mengukur seberapa jauh kemampuan variabel independen dalam menjelaskan variasi variabel dependen. Nilai koefisien determinasi adalah antara nol dan satu.

Tabel 2

Koefisisen Determinan

Model Summary ${ }^{b}$

\begin{tabular}{|l|l|r|r|r|}
\hline Model & $\mathrm{R}$ & $\mathrm{R}$ Square & $\begin{array}{c}\text { Adjusted R } \\
\text { Square }\end{array}$ & $\begin{array}{r}\text { Std. Error of } \\
\text { the Estimate }\end{array}$ \\
\hline 1 & $.554^{\mathrm{a}}$ & .306 & .226 & .04743 \\
\hline
\end{tabular}

a. Predictors: (Constant), UP (X3), PROPER (X2), ROA (X1)

b. Dependent Variable: ISR $(Y)$

Berdasarkan tabel diatas, diperoleh nilai Adjusted $R$ square sebesar 0,226. Hasil ini berarti menunjukkan bahwa terdapat pengaruh nilai perusahaan dipengaruhi oleh variabel independen return on asset dan program penilaian peringkat terhadap islamic social reporting melalui ukuran perusahaan sebesar 0,226 atau $2,6 \%$.

\section{3) Uji hipotesis}

Uji hipotesis merupakan uji yang berupa langkah pembuktian dengan penelitian. Langkah ini bertujuan untuk menguji kebenaran hipotesis yang dikemukakan oleh peneliti secara linear.

\section{4) Hasil uji F (Simultan)}

Pengujian ini digunakan untuk melihat apakah secara keseluruhan variabel independen mempunyai pengaruh yang bermakna terhadap variabel dependen. Dari hasil pengujian dengan nilai $F$ diperoleh sebagai berikut :

Tabel 3

Hasil Output SPSS

Uji Regresi Linier Berganda Secara Simultan (F)

ANOVA $^{\mathrm{a}}$

\begin{tabular}{|l|r|r|r|c|c|}
\hline Model & Sum of Squares & df & Mean Square & F & Sig. \\
\hline 1 Regression & .026 & 3 & .009 & 3.829 & $.021^{\mathrm{b}}$ \\
Residual & .058 & 26 & .002 & & \\
Total & .084 & 29 & & & \\
\hline
\end{tabular}

a. Predictors: (Constant), UP (X3), PROPER (X2), ROA (X1)

b. Dependent Variable: ISR $(Y)$ 
Berdasarkan tabel diatas didapat nilai Fhitung sebesar 2,885 sedangkan Ftabel dengan taraf nyata (n) sebesar $5 \%$ serta $\mathrm{df}=\mathrm{n}-\mathrm{k}-1=30-3-$ $1=26$ jadi Ftabel sebesar 1.70562 maka disimpulkan bahwa Fhitung > Ftabel $(3,829>1,70562)$ dan tingkat signifikan 0,05 $(0.021<0,05)$ didapat nilai $\mathrm{F}$ sig $0.021<0.05$ dan Fhitung 3,829>1.70562 Ftabel maka $\mathrm{HO}$ ditolak dan $\mathrm{Ha}$ berpengaruh yang artinya bahwa return on asset, program penilaian peringkat dan ukuran perusahaan berpengaruh dan signifikan terhadap islamic social reporting.

\section{5) Hasil uji t (Parsial) \\ Pengujian hipotesis secara} individual merupakan pengujian hipotesis koefisien regresi berganda dengan hanya satu b (b1 atau b2 atau b3 atau b4) yang mempengaruhi $Y$. Untuk menjawab permasalahan pengaruh return on asset, program penilaian peringkat, dan ukuran perusahaan maka hasilnya diuji dengan menggunakan uji t. Dibawah ini menjelaskan mengenai hasil analisis regresi yang dilakukan.

Tabel 4

Hasil Output SPSS

Uji Rregresi Linier Berganda Secara Parsial (t)

Coefficients $^{a}$

\begin{tabular}{|l|r|r|r|r|r|}
\hline \multirow{2}{*}{ Model } & \multicolumn{2}{|c|}{$\begin{array}{c}\text { Unstandardized } \\
\text { Coefficients }\end{array}$} & $\begin{array}{c}\text { Standardized } \\
\text { Coefficients }\end{array}$ & & \multirow{2}{*}{ Sig. } \\
\cline { 2 - 5 } & \multicolumn{1}{|c|}{$\mathrm{B}$} & Std. Error & \multicolumn{1}{|c|}{ Beta } & \multicolumn{1}{c|}{$\mathrm{t}$} & Sig. \\
\hline 1 (Constant) & -.151 & .226 & & -.669 & .049 \\
ROA & .017 & .010 & .325 & 1.709 & .042 \\
PROPER & .023 & .045 & .092 & .515 & .611 \\
UP & .016 & .007 & .376 & 2.163 & .040 \\
\hline
\end{tabular}

a. Dependent Variable: ISR

Berdasarkan Tabel diatas hasil analisis diperoleh data bahwa thitung untuk return on asset sebesar 1,709 dengan signifikan 0,099, thitung untuk program penilaian peringkat sebesar 0,515 dengan signifikan 0,611, thitung untuk ukuran perusahaan sebesar 2,163 dengan signifikan 0,040.

\section{Pengaruh Return On Asset Terhadap Islamic Social Reporting.}

Hasil uji hipotesis return on asset terhadap islamic social reporting didapat nilai signifikan return on asset t sig $0,099>0,05$ dan nilai thitung $1,709>1.70562$ t-tabel maka $\mathrm{HO}$ ditolak dan $\mathrm{Ha}$ diterima yang artinya return on asset berpengaruh terhadap islamic social reporting pada perusahaan yang terdaftar di indeks saham syariah indonesia.

\section{$>\quad$ Pengaruh Program Penilaian Peringkat Terhadap Islamic Social Reporting.}

Hasil uji hipotesis program penilaian peringkat terhadap islamic social reporting didapat nilai signifikan program penilaian peringkat $t$ sig $0,577>0,05$ dan nilai thitung $0,564<$ 1.70562 t-tabel maka $\mathrm{HO}$ ditolak dan $\mathrm{Ha}$ diterima yang artinya program penilaian peringkat berpengaruh terhadap islamic social reporting pada 
perusahaan yang terdaftar di indeks saham syariah Indonesia.

\section{$>\quad$ Pengaruh Ukuran Perusahaan Terhadap Islamic Social Reporting.}

Hasil uji hipotesis ukuran perusahaan terhadap islamic social reporting didapat nilai signifikan ukuran perusahaan $\mathrm{t}$ sig $0,034>0,05$ dan nilai thitung $2.244>1.70562 \mathrm{t}-$ tabel maka $\mathrm{HO}$ ditolak dan $\mathrm{Ha}$ diterima yang artinya ukuran perusahaan berpengaruh terhadap islamic social reporting pada perusahaan yang terdaftar di indeks saham syariah Indonesia.

\section{E. PEMBAHASAN}

\section{1) Pengaruh Return On Asset dan Program Penilaian Peringkat terhadap islamic social reporting}

Hasil penelitian secara bersamasama menunjukkan bahwa return on asset dan program penilaian peringkat berpengaruh terhadap islamic social reporting. Semakin tinggi return on asset dan program penilaian peringkat juga akan meningkatkan laba perlembar saham perusahaan akan membuat investor tertarik untuk menanamkan modalnya dengan membeli saham perusahaan, dengan banyaknya investor yang membeli saham perusahaan maka akan menaikkan harga saham perusahaan tersebut sehingga akan meningkatkan nilai perusahaan.

\section{2) Pengaruh Return On Asset Terhadap Pengungkapan Islamic Social Reporting.}

Berdasarkan penelitian yang diperoleh bahwa return on asset tidak berpengaruh yang signifikan terhadap variabel islamic social reporting. Perusahaan yang memiliki return on asset yang rendah tidak akan mendapatkan dana yang cukup, sehingga perusahaan tidak dapat meningkatkan kinerja yang berakibatkan pada penurunan pada islamic scial reporting. Perusahaan yang tidak berhasil meningkatkan return on asset setiap tahunnya, maka tidak akan membuat ketertarikan banyak investor.

\section{3) Pengaruh Program Penilaian Peringkat Terhadap Islamic Social Reporting.}

Berdasarkan penelitian yang diperoleh bahwa program penilaian peringkat berpengaruh dan signifikan mempengaruhi variabel islamic social reporting. Program penilaian peringkat dari keseluruhan yang masuk dalam sampel penelitian menunjukan nilai peringkat baik. Berdasarkan teori, kinerja lingkungan dapat menggambarkan suatu perusahaan memiliki perilaku peduli lingkungan atau tidak, dimana perusahaan dengan kinerja lingkungan yang tinggi akan mendapatkan nilai positif dalam pandangan masyarakat dan investor.

\section{4) Pengaruh Return On Asset Terhadap Ukuran Perusahaan.}

Berdasarkan penelitian yang diperoleh bahwa return on aset tidak terdapat pengaruh secara langsung terhadap ukuran perusahaan. Perusahaan yang memiliki return on asset yang rendah tidak akan mendapatkan dana yang cukup, sehingga perusahaan tidak dapat meningkatkan kinerja yang berakibatkan pada penurunan pada ukuran perusahaan. Perusahaan yang tidak berhasil meningkatkan return on asset setiap tahunnya, maka tidak akan membuat ketertarikan banyak investor. 


\section{5) Pengaruh Program Penilaian Peringkat Terhadap Ukuran Perusahaan.}

Berdasarkan penelitian yang diperoleh bahwa program penilaian peringkat positif dan signifikan mempengaruhi ukuran perusahaan. Berdasarkan teori, kinerja lingkungan dapat menggambarkan suatu perusahaan memiliki perilaku peduli lingkungan atau tidak, dimana perusahaan dengan kinerja lingkungan yang tinggi akan mendapatkan nilai positif dalam pandangan masyarakat dan investor.

\section{6) Pengaruh Return On Asset Dan Program Penilaian Peringkat Terhadap Pengungkapan Islamic Social Reporting Melalui Ukuran Perusahaan Sebagai Variabel Intervening.}

Berdasarkan uji analisis yang telah dilakukan menggunakan Analysis of Moment Structure (AMOS) menunjukkan bahwa return on asset secara tidak langsung berpengaruh terhadap islamic social reporting melalui ukuran perusahaan dan program penilaian peringkat berpengaruh secara langsung terhadap islamic social reporting melalui ukuran perusahaan. Hal ini sejalan dengan teori Hery (2016: 97) mendefinisikan ukuran perusahaan merupakan skala yang menunjukkan besar atau kecilnya suatu perusahaan. Hery (2017) menyatakan bahwa ukuran perusahaan melalu total aset cenderung lebih stabil dari pada melalu penjualan.

\section{F. KESIMPULAN DAN SARAN \\ 1) Kesimpulan \\ Berdasarkan data yang telah dikumpulkan dan hasil pengujian,}

maka hasil penelitian ini dapat ditarik kesimpulan bahwa :

a) Return on asset, program penilaian peringkat dan ukuran perusahaan berpengaruh terhadap islamic social reporting.

b) Dapat dilihat dari hasil Uji Parsial (Uji $\mathrm{t}$ ), dari Pengaruh return on asset berpengaruh terhadap islamic social reporting.

c) Pengaruh program penilaian peringkat berpengaruh signifikan terhadap islamic social reporting.

d) Pengaruh return on asset tidak terdapat pengaruh secara langsung terhadap signifikan mempengaruhi variabel islamic social reporting.

\section{2) Saran}

Berdasarkan kesimpulan dalam penelitian, penulis dapat memberikan beberapa saran yaitu :

a) Menambahkan periode penelitian agar perubahanperubahan yang terjadi dalam tingkat pengungkapan islamic social reporting (ISR) antara periode dapat terlihat.

b) Peneliti selanjutnya disarankan untuk menambah periode penelitian sehingga sampel penelitian yang digunakan lebih banyak.

c) Penelitian selanjutnya dapat mengembangkan variabel independen yang dapat mempengaruhi pengungkapan islamic social reporting (ISR).

d) Untuk pemerintah dan lembaga keuangan yang berwenang agar bisa menetapkan standar pengungkapan islamic social reporting (tanggungjawab sosial secara syariah), agar pengungkapan tanggungjawab secara konvensional dan syariah dapat dibedakan. 
DAFTAR PUSTAKA

Hery. 2017. Analisis Laporan Keuangan (Cetakan Kedua). Jakarta: Grasindo.

Hery. 2017. Kajian Riset Akuntansi Mengulas Berbagai Hasil Penelitian Terkini dalam Bidang
Akuntansi dan Keuangan. Jakarta: Grasindo.

Irham Fahmi. 2015. Analisis Kinerja Keuangan. Jakarta: Alfabeta.

Yasir Yusuf. 2017. Islamic Corporate Social Responsibility pada Lembaga Keuangan Syariah. Depok: Kencana. 